\title{
POKUS O VÝKLAD NIEKTORÝCH OTÁZNYCH SPÔSOBOV DEPONOVANIA KOPIJÍ A OŠTEPOV DO HROBOV VČASNOSTREDOVEKEJ KARPATSKEJ KOTLINY ${ }^{1}$
}

\author{
An Attempt to Explain Some Debatable Ways of Depositions of Spears, \\ Lances, or Javelins in Graves of the Early Medieval Carpathian Basin
}

\author{
Martin Husár
}

DOI: 10.17846/CL.2018.11.1.51-66

\begin{abstract}
HUSÁR, Martin. An Attempt to Explain Some Debatable Ways of Depositions of Spears, Lances, or Javelins in Graves of the Early Medieval Carpathian Basin. In his article, the author dealt with debatable ways of depositions of the early medieval spears, lances, and javelins (thrusting pole arms) in graves from the Carpathian Basin. The time frame of the article is, in the given region, connected with the period of the Avar Khaganate, then with the 9th century and finally the period of the 10th - 11th centuries. Martin Husár identified the following ways of spears, lances, or javelins' depositions in the aforementioned graves as debatable or questionable: the sticking into walls of a grave pit, oblique deposition over and under the deceased or a dead horse, deposition within a wooden construction or outside of it, deposition on or under a wooden construction, horizontal deposition in the filling of a grave, vertical sticking into the filling and the bottom of a grave, possible killing of a horse by a thrusting pole weapon deposited in a grave and the deposition of a deformed or broken head of a thrusting pole weapon. It can be stated that only during the period of the Avar Khaganate, all eight abovementioned ways of depositions were carried out.
\end{abstract}

Keywords: spears, lances, javelins, Early Middle Ages, Carpathian Basin, graves, debatable ways of depositions

\begin{abstract}
Abstrakt: HUSÁR, Martin. Pokus o výklad niektorých otáznych spôsobov deponovania kopijí a oštepov do hrobov včasnostredovekej Karpatskej kotliny. Autor sa vo svojom príspevku zaoberal otáznymi spôsobmi deponovania včasnostredovekých kopijí a oštepov (žrdovo-bodných zbraní) do hrobov v Karpatskej kotline. Časový záber príspevku sa v danom priestore viazal na obdobie avarského kaganátu, 9. storočie a 10. a 11. storočie. Martin Husár identifikoval a označil za otázne alebo diskutabilné nasledovné spôsoby ukladania žrdovo-bodných zbraní do hrobových celkov: zabodávanie do stien hrobovej jamy, šikmé uloženie nad a pod zomrelým alebo koňom, uloženie v rámci drevenej konštrukcie a mimo nej, uloženie na a pod drevenou konštrukciou, horizontálne uloženie v zásype hrobu, vertikálne zabodnutie v zásype a na dne hrobu, možné zabitie koňa kopijou/oštepom nájdenou v hrobe a uloženie deformovaného alebo zlomeného hrotu kopije/oštepu. Dá sa konštatovat, že len počas obdobia avarského kaganátu sa praktizovalo všetkých osem spomenutých spôsobov deponovania.
\end{abstract}

Klúčové slová: kopije, oštepy, včasný stredovek, Karpatská kotlina, hroby, otázne spôsoby deponovania

1 Štúdia vznikla v rámci riešenia projektu KEGA č. 004UKF-4/2018 Európsky stredovek interaktívne. 
Otázne spôsoby deponovania žrd’ovo-bodných zbraní, kopijí a oštepov, v hrobových celkoch Karpatskej kotliny v období včasného stredoveku, konkrétne od poslednej tretiny 6. do 10. až 11 . storočia, ${ }^{2}$ neboli v odbornej literatúre, až na určitú výnimku z pera autora tohto článku (Husár 2015, $7-26)^{3}$, doteraz ucelene a uspokojivo posudzované. ${ }^{4}$ Ide o také spôsoby ukladania kopijí/oštepov, ktoré môžu vyvolávat otázky týkajúce sa dôvodu ich realizácie alebo dôsledkov ich uloženia.

V rámci daných spôsobov ukladania si budem všímat', okrem neporušených hrobových celkov, v niektorých prípadoch aj porušené ${ }^{5}$ hrobové celky. Je tomu tak kvôli špecifickej povahe určitých otáznych spôsobov deponovania kopijí a oštepov. Spomenutie daných porušených hrobov v texte náležite zdôrazním. K otáznym spôsobom uloženia zaradujem konkrétne prípady v nasledujúcich riadkoch. O nich sa nazdávam, že by mohli byt k takýmto spôsobom svojou povahou zaradené.

\section{Zabodávanie do stien}

Najprv sa zameriam na prípady, kedy boli žrd’ovo-bodné zbrane zapichnuté v stenách hrobových jám. Na niektorých pohrebiskách z územia Panónie boli hroty zapichnuté v stenách hrobov a zároveň umiestnené mimo truhiel alebo drevených hrobových konštrukcií obsiahnutých v daných včasnoavarských hroboch. Konkrétne tomu tak bolo v hrobe 104 a 124 na pohrebisku Környe (Salamon - Erdélyi 1971, 24, 26, Taf. 38) a v hrobe B-80 na pohrebisku Kölked-Feketekapu B (Kiss 2001a, 26, Abb. 7; 2001b, Taf. 26: 2; 27: 2; 103: 2). Hrot osti (harpúny) z porušeného hrobu 881 na pohrebisku Zamárdi-Réti földek dűlő (Bárdos - Garam 2009, 119, Taf. 104: 3) bol však už asi zapichnutý do truhly. V porušenom hrobe 1634 z pohrebiska Zamárdi-Réti földek dűlő (tab. 1: 1; Bárdos - Garam 2009, 30, 32, Taf. 179: 26, Abb. 14) ${ }^{7}$ tomu bolo však tak, že hrot kopije/oštepu bol zabodnutý v stene hrobu, ktorý neobsahoval vyššie spomenuté drevené konštrukcie.

2 V priestore Karpatskej kotliny sledujem epochu, ktorá sa začala príchodom Avarov v rokoch 567 - 568 do nej $($ Pohl 1988, 496) a skončila sa obdobím medzi poslednou tretinou 10. storočia a začiatkom 11. storočia, ked’ sa zbrane prakticky vytratili z príloh hrobových celkov v danej oblasti (Hanuliak 1990, 160; Kovács 1982, 251).

3 V danom príspevku som sa zaoberal otáznymi spôsobmi deponovania preberaných zbraní v priestore včasnostredovekej Karpatskej kotliny však len čiastočne, konkrétne na príklade neporušených hrobových celkov, a nie tažiskovo a komplexne (Husár 2015, 9-11, Plate 3-6).

4 Medzi práce, ktoré poskytujú prospešné analógie pre pertraktovanú tému, zaradujem najmä prácu polského archeológia Tomasza Kurrasińskeho $(2014,159-190)$ zaoberajúcu sa ukladaním kopijí/oštepov do hrobov na území dnešného Pol’ska vo včasnom stredoveku. Nenahraditelné informácie poskytuje i monografia Anne Pedersenovej v dvoch zväzkoch (2014a; 2014b), ktorá sa týka hrobov jazdcov a hrobov so zbraňami z územia súčasného Dánska medzi rokmi 800 až 1000 . Podstatné poznatky o ukladaní (Liana 1968, 381-385) hrotov žrdovo-bodných zbraní do hrobových celkov Przeworskej kultúry (trvajúcej predovšetkým na časti územia súčasného Polska od doby laténskej do doby stahovania národov) a tiež o ich deformovaní a ničení (Czarnecka - Kontny 2009, 29-40) máme sprostredkované v článkoch niektorých polských bádatelov. Tiež treba dodat, že Gergely Csiky (2015) sa vo svojej monografii o žrd’ových zbraniach a zbraniach s ostrím $\mathrm{z}$ doby avarskej nevenoval otáznym alebo diskutabilným spôsobom deponovania kopijí/oštepov, no len ich uložením vo vztahu k častiam tela alebo kostry zomrelého či koňa (Csiky 2015, 362-372). Nenahraditel’né etnografické pozorovania, ktoré nám môžu vnášat určité svetlo do niektorých pre nás už otáznych spôsobov ukladania žrdovo-bodných zbraní do hrobov národov európskych či ázijských stepí, nám prináša monografia Abdesha Tashkenovicha Toleubayeva (2013).

5 Celkový počet hrobov vhodných na výskumnú analýzu dosahuje číslo 597, z nich evidujem 150 ako porušených hrobových celkov a 9 hrobov len ako pravdepodobne porušených (stav k 28. februáru 2018).

6 Uvedený hrobový celok môže byt zaradený iba rámcovo do obdobia od roku 568 do 8. storočia (Bárdos Garam 2009, 9).

7 Hrob je možné datovat len rámcovo do obdobia od roku 568 do 8. storočia (Bárdos - Garam 2009, 9). 
V tomto ohlade treba tiež podotknút, že už v neskorolaténskom urnovom hrobe $144 \mathrm{z}$ pohrebiska Przeworskej kultúry v Karczewieci sa objavil hrot kopije/oštepu zabodnutý v hrobovej stene (Liana 1968, 381). Takisto hrot žrdovo-bodnej zbrane z hrobu Bj.834 na pohrebisku Birka vo Švédsku, ktorý je možné zaradit do 10. storočia (Price 2004, 115), bol zabodnutý do drevenej konštrukcie v rámci daného hrobu patriaceho páru zomrelých - mužovi a žene - pochovaných s koňmi (tab. 1: 2; Kurasiński 2014, 168; Price 2008, 268, Fig. 19.4).

\section{Šikmo nad a pod zomrelým alebo koňom}

V nasledujúcich prípadoch mohol byt’ oštep alebo kopija umiestnená šikmo nad alebo pod zomrelým či koňom. Diagonálne pod zomrelým sa našiel hrot v hrobe CLIX na pohrebisku Band zo včasného stupňa obdobia avarského kaganátu ${ }^{8}$ (Kovács, I. 1913, 355, 357). Hrobové celky, v ktorých boli žrd’ovo-bodné zbrane umiestnené nad zomrelými či koňmi, patria k piatim včasno- alebo neskoroavarským ${ }^{9}$, ako aj dvom velkomoravským celkom datovaným medzi roky 800 a $860^{10}$.

$\mathrm{V}$ rámci vikingských hrobových celkov 10 . storočia v Dánsku by som vedel poukázat na niekolko prípadov, kedy bola žrdovo-bodná zbraň uložená cez zomrelého (Pedersen 2014a, 177). V hrobe FII z pohrebiska Stengade II (Dánsko), datovaného do rovnakého obdobia, bola 2,35 m dlhá kopija/oštep dokonca šikmo uložená ponad dvoch zomrelých mužov (Pedersen 2014a, 90; 2014b, 35, 78).

\section{V rámci drevenej konštrukcie a mimo nej}

Žrd’ovo-bodné zbrane boli deponované rôznym spôsobom v hrobových celkoch obsahujúcich truhlu či drevenú konštrukciu. $\mathrm{V}$ rámci drevených konštrukcií $\mathrm{v}$ týchto neporušených hrobových celkoch bolo uložených 13 hrotov kopijí/oštepov. Navzdory tomu, že väčšina hrotov preberaných zbraní sa dala časovo stotožnit so začiatkom 9. storočia až polovicou 10. storočia, ${ }^{11}$ ostatných

8 Zhruba medzi rokmi 568 a 650.

9 Hrob 199 (tab. 1: 3), 507 a 1149 z pohrebiska Tiszafüred-Majoros (Garam 1995, 32, 68, 135, Abb. 12, 28, 55; všetky hroby sa dajú zaradit do rokov 720 - 750), jazdecký hrob z Biharkeresztes-Lencséshát (Mesterházy 1987, 222, 243, 5. kép; Szentpéteri 2002, 58; hrob je možné datovat do rokov 568 - 600), a hrob 258 z pohrebiska Štúrovo (Točík 1968a, 68, Taf. LI: 14-15, Abb. 33; Zábojník 1995, Tabelle III; hrob môžeme zaradit do rokov 720 - 750). V prvých troch spomenutých hrobových celkoch bola žrdovo-bodná zbraň uložená šikmo cez peších bojovníkov, $\mathrm{v}$ dalšom hrobe cez jazdca a v poslednom hrobe cez pochovaného koňa. V hrobe zo Štúrova môže byt diagonálne deponovanie kopije/oštepu cez koňa jazdca podopreté aj tým, že popri hrote ukončovala túto zbraň na jej opačnom konci i pätka (Toč́́k 1968a, Abb. 33).

10 V prvom rade ide o hrob 587 z pohrebiska Čakajovce-Kostolné (Rejholcová 1995b, 64, tab. XCIV: 2, 3; CXL: 5), kde bolo šikmé uloženie hrotu kopije/oštepu cez mútveho muža zistené nielen pomocou uloženia jeho hrotu, ale i pätky. Diagonálne deponovaná kopija/oštep, čo bolo zistené však len na základe jeho hrotu, bola i v hrobe 2/63 z Nitry-Dolných Krškán-Skladov OD Prior (Chropovský 1986, 16; Hanuliak 2004, 269). Oba spomenuté hrobové celky boli zaradené do rokov 800 - 860 (Hanuliak - Rejholcová 1999, 49; Hanuliak 2004, 269).

11 Hrob 39 z pohrebiska Michal nad Žitavou-Domovina (Točík 1971, 197, 198, Abb. 72; Hanuliak 2004, 267; hrob môžeme zaradit do obdobia od roku 800 do polovice 10. storočia), hrob 2/63 z pohrebiska Nitra-Dolné Krškany-Sklady OD Prior (Chropovský 1986, 16; Hanuliak 2004, 269, tab. LIX: 14; LX: 1-4, 12; hrob je možné datovat do rozmedzia rokov 800 - 860), hrob 30 (Török 1973, 14, 107; 5. ábra; hrob sa dá zaradit', ako aj celé pohrebisko, do 9. storočia), 48 (Török 1973, 16, 107; 7. ábra; hrob sa dá zaradit, ako aj celé pohrebisko, do 9. storočia), 60 (tab. 1: 4; Török 1973, 18; 9. ábra; hrob vieme konkrétne datovat na začiatok 9. storočia), 78 (Török 1973, 21, 107; 12. ábra; hrob sa dá zaradit', ako aj celé pohrebisko, do 9. storočia), 92 (Török 1973, 
pät hrotov bolo datovaných do obdobia avarského kaganátu ${ }^{12}$. Naopak najväčšie množstvo pertraktovaných hrotov, konkrétne 11 ks, ktoré boli umiestnené mimo truhly alebo inej drevenej konštrukcie, je zaradená do obdobia avarského kaganátu ${ }^{13}$. Zostávajúce štyri exempláre $\mathrm{z}$ danej kategórie vieme datovat do 9 . storočia až prvej polovice 10. storočia. ${ }^{14}$ Dokonca jeden hrot kopije/ oštepu bol deponovaný vo vel'komoravskom $(800$ - 860) hrobe (č. 85) s výklenkom na pohrebisku Cífer-Pác (Fusek 2006, 32, 40, tab. III: 1; obr. 7-9) a je pravdepodobné, že celá zbraň či len jej čast’ bola opretá o stenu výklenku. Na základe nálezovej situácie môžeme konštatovat', že táto zbraň bola najpravdepodobnejšie zlomená, rovnako i exemplár z hrobu 2354 z pohrebiska Zamárdi-Réti földek dűlő, v ktorom bol pochovaný kôň. Hrot tejto žrdovo-bodnej zbrane bol objavený vedla lavej prednej nohy pôvodne uloženého koňa, avšak špička daného hrotu smerovala k nohám koňa (Bárdos - Garam 2014, 142, Abb. 71; 72: 2354). ${ }^{15}$

Do kontextu týchto prípadov zapadá i poznatok o žrdi kopije s krídelkami z hrobu IV (umiestneného pod mohylou) v rámci vikingského pohrebiska Süderbrarup v Dánsku, ktorú prelomili tesne pod tulajkou hrotu. Väčšiu čast̉ žrde potom odstránili. Následne bola pätka, pravdepodobne z rovnakej zbrane, pripojená $\mathrm{k}$ zvyšku násady v tulajke hrotu. Navyše vieme povedat, že tulajka bola i otočená k stene hrobovej jamy (Pedersen 2014a, 90; 2014b, 106, Plate 50: 3). Hrot z vnútra rakvy $\mathrm{v}$ rámci mohyly $\mathrm{z}$ Ballateare, $\mathrm{z}$ lokality nachádzajúcej sa na Isle of Man v Spojenom královstve, ktorá bola vytvorená v neskorom 9. a včasnom 10. storočí, ležal vedl’a lavej ruky muža a smeroval svojou špičkou dolu, $\mathrm{k}$ nohám zomrelého. $\mathrm{Z}$ tohto dôvodu mohol patrit k zbrani, ktorá bola zlomená, a týmto činom skrátená, aby sa vošla do relatívne malej truhly (Holman 2012; Kurasiński 2014, 168; Gardeła 2014, 32, Fig. 10).

V tejto súvislosti treba spomenút i to, že napríklad Kazachovia lámali kopiju/oštep (naiza) $\mathrm{v}$ mieste jej žrde rok po smrti mŕtveho, ktorému patrila, a to v rámci rozlúčkovej ceremónie.

23, 107; 13. ábra; hrob vieme datovat', ako aj celé pohrebisko, do 9. storočia), a 128 (Török 1973, 29, 107; 3. tábla: 4; hrob sa dá zaradit', ako aj celé pohrebisko, do 9. storočia) z pohrebiska Sopron-Sopronkőhida.

12 Hrob 82 z pohrebiska Pókaszepetk-Mesterföldek, Avar u. (Sós - Salamon 1995, 89, 145, fig. 25; hrob podla všetkého patrí do I. horizontu pochovávania na pohrebisku, to jest pred rok 630), hrob 577 (Garam 1995, 76, Abb. 35; hrob sa dá zaradit' do obdobia rokov 650 - 675) a 1149 z pohrebiska Tiszafüred-Majoros (Garam 1995, 135, Abb. 55; hrob môže spadat' do rokov 720 - 750) a hrob 1653 a 2354 z pohrebiska Zamárdi-Réti földek dűlő (Bárdos - Garam 2014, 34, 142, Abb. 16: 1653 a-b; 71; 72: 2354; prvý hrob $\mathrm{z}$ uvedenej dvojice vieme zaradit’ do druhej polovice 7. storočia až prvej polovice 8 . storočia a druhý hrob do priebehu 8. storočia).

13 Hrob B-80 z pohrebiska Kölked-Feketekapu B (Kiss 2001a, 26, Abb. 6, 7, 185; 2001b, Taf. 26: 2; 27: 2; 103: 2; hrob patrí do IX. skupiny hrobov v rámci horizontálnej stratigrafie na danom pohrebisku, a takto do rokov 568 - 625), hrob 104 a 124 z pohrebiska Környe (Salamon - Erdélyi 1971, 24, 26, Taf. 38; oba hrobové celky patria časovo do rokov 568 - 650), hrob 496 (tab. 1: 5; Garam 1995, 65, Abb. 27; hrob vieme zaradit' do obdobia rokov 720 - 750), 507 (Garam 1995, 68, Abb. 28; podla hrobových príloh sa celý hrobový celok dá zaradit’ do rokov 720 - 750), 592 (Garam 1995, 78, Abb. 33; hrob môže byt' datovaný do rokov 720 - 750), 721 (Garam 1995, 91, Abb. 36; hrob sa dá zaradit, ako i samotné pohrebisko, rámcovo od polovice 7 . do 8. storočia), 937 (Garam 1995, 111, Abb. 37; hrob vieme datovat' do druhej polovice 7. storočia), 1003 (Garam 1995, 118, Abb. 48; časové zaradenie hrobového celku spadá do rokov 720 - 750), 1142 (Garam 1995, 135; hrob vieme datovat' do rokov 750 - 780), a 1246 (Garam 1995, 150, Abb. 62; hrob sa dá podla hrobových príloh zaradit' do rokov 750 - 780) z pohrebiska Tiszafüred-Majoros.

14 Hrob 24 z pohrebiska Michal nad Žitavou-Domovina (Hanuliak 2004, 267; Točík 1971, 195, 196, Abb. 69; hrob vieme zaradit' od 9. storočia do polovice 10. storočia), hrob 84 a 127 z pohrebiska Sopron-Sopronkőhida (Török 1973, 22, 28, 107, 1. tábla 3; 3. tábla: 3; oba hrobové celky sa dajú datovat do 9. storočia), a hrob 89 z pohrebiska Vel'ký Grob-Za potoky (Chropovský 1957, 184, obr. 10; Štefanovičová 1996, 261-262; hrob je možné zaradit’ do prvej polovice 9 . storočia).

15 Hrob sa dá na základe hrobových príloh zaradit’ do 8. storočia. 
Oni totiž verili, že táto kopija/oštep, aj spolu s inými jeho osobnými vecami či zvieratami, je ešte stále vo vlastníctve duše zomrelého (jeho duša je v nich). Takto by potom mohla ohrozovat žijúcich, keby ju (i s ostatným osobným majetkom zomrelého) zanechali neporušenú na tomto svete (Solov’ev 2003, 215, poznámka 3; Toleubayev 2013, 163-164).

\section{$\mathrm{Na}$ a pod drevenou konštrukciou}

Tri hroty žrd’ovo-bodných zbraní z posudzovaného súboru boli velmi pravdepodobne položené na truhlu ${ }^{16}$ a rovnako tri iné hroty boli deponované pod truhlou či inou konštrukciou $\mathrm{z}$ dre$\mathrm{va}^{17}$. Tieto hrobové celky sú datované do obdobia avarského kaganátu i nasledujúceho obdobia 9. storočia.

K daným skutočnostiam treba dodat, že v už vyššie spomínanej mohyle z lokality Ballateare boli umiestnené spolu až tri hroty kopijí/oštepov. Dve kopije/oštepy z uvedených boli uložené na veko truhly a ostatný jeden bol vo vnútri truhly spolu s ostatkami zomrelého muža (Holman 2012; Kurasiński 2014, 168; Gardeła 2014, 32, Fig. 10).

\section{Horizontálne v zásype hrobu}

V zásypoch hrobov sa niektoré hroty kopijí/oštepov našli vo viac-menej horizontálnej polohe, presnejšie niekolko centimetrov nad dnami týchto hrobov. Niektoré uvedené uloženia mohli však odzrkadlovat bežné rozloženie hrobových príloh na alebo mierne nad dnami hrobov. K takýmto hrobovým celkom môžeme najpravdepodobnejšie priradit pät hrobov z obdobia avarského kaganátu, kde boli hroty žrd’ovo-bodných zbraní deponované bud' len vo výške 10-30 cm nad dnami hrobových jám, alebo potom $\mathrm{v}$ neznámej výške nad spomenutými dnami. ${ }^{18} \mathrm{~V}$ dvoch $\mathrm{z}$ nich sa

16 Hrob B-443 z pohrebiska Kölked-Feketekapu B (Kiss 2001a, 142, Abb. 42; Kiss 2001b, Taf. 82: 4; hrob je možné priradit $\mathrm{k}$ V. skupine hrobov v rámci horizontálnej stratigrafie na spomenutom pohrebisku, to jest do rokov 568 - 680), hrob 16 z pohrebiska Sopron-Sopronkőhida (Török 1973, 11-12, 107, 3. ábra; hrob vieme datovat, ako i samotné pohrebisko, ku ktorému prislúcha, do 9. storočia), a hrob $968 \mathrm{z}$ pohrebiska Tiszafüred-Majoros (Garam 1995, 114, Abb. 45; hrob sa dá zaradit’ do rokov 720 - 750).

17 Hrob 28 z Cífera-Pácu (Čilinská 1976, 83; ak vychádzame z hrobových príloh, hrob spadá do rokov 720 750), hrob 17 z pohrebiska Páli-Dombok (Tomka 2000, 188, 190, 202 Abb. 10: 1; hrob sa dá zaradit do rokov 800 - 860), a hrob 945 z pohrebiska Tiszafüred-Majoros (Garam 1995, 112; hrob patrí do obdobia rokov 720 - 750). V už vyššie uvedenom hrobe 28 z pohrebiska Cífer-Pác bol hrot identifikovaný $7 \mathrm{~cm}$ pod kolovou jamkou tu sa nachádzajúcej drevenej konštrukcie, čo konkrétne činí $22 \mathrm{~cm}$ pod úrovňou dna hrobovej jamy (Čilinská 1976, 83).

18 Hrob A-107 a A-316 z pohrebiska Kölked-Feketekapu A (Kiss 1996, 42, 90; oba hroby sa dajú zaradit do rokov 568 - 650; v prvom hrobovom celku sa hrot kopije/oštepu našiel vo výške cirka $20-22 \mathrm{~cm}$ a v druhom zase $28 \mathrm{~cm}$ nad dnom hrobu), hrob B-82 z pohrebiska Kölked-Feketekapu B (Kiss 2001a, 28, Abb. 7, 8, 185; hrob patrí do IX. skupiny hrobov v rámci horizontálnej stratigrafie na uvedenom pohrebisku, čo v absolútnych číslach znamená obdobie rokov 568 - 625; hrot kopije/oštepu bol identifikovaný vo výške len 10 cm nad dnom hrobu), 231 (Garam 1995, 36, Abb. 254; hrob sa dá zaradit do 1. fázy pochovávania na danom pohrebisku, čo v absolútnych číslach znamená obdobie rokov 650 - 670; hrot kopije/ oštepu sa objavil v neznámej hĺbke vo výplni hrobu), 709 (Garam 1995, 90; na základe hrobových príloh sa dá hrob zaradit’ do rokov 650 - 700; hrot kopije/oštepu sa identifikoval vo výške $20 \mathrm{~cm}$ nad kostrou zomrelého, ktorá bola uložená v rakve) a 757 (Garam 1995, 94; hrob vieme datovat’ do rokov 650 - 675; hrot kopije/oštepu bol objavený vo výške $30 \mathrm{~cm}$ na kostrou zomrelého uloženého v rakve) z pohrebiska Tiszafüred-Majoros. 
pôvodne nachádzala i drevená rakva. ${ }^{19}$ Naproti tomu v hrobe 551 z pohrebiska v Holiaroch (Točík 1968b, 85; hrob môže byt na základe hrobových príloh zaradený do rokov 700 - 720) sa hrot žrd’ovo-bodnej zbrane identifikoval vo výške $50 \mathrm{~cm}$ nad dnom daného hrobu a drevená konštrukcia tu úplne absentovala. Myslím si, že za určitých okolností mohla byṫ kopija/oštep uložená do tohto hrobu až po prikrytí jazdca zeminou.

Urna z hrobu 439 na pohrebisku Bratislava, Devínska Nová Ves-Tehelňa (Eisner 1952, 100; Zábojník 1995, Tabelle III; 2009, 81; hrob sa dá zaradit len rámcovo, ako aj celé pohrebisko, od druhej polovice 7. do 8. storočia), bola prikrytá kameňom a hrotom kopije/oštepu. Hrot žrd’ovo-bodnej zbrane bol položený tiež na urne z hrobu 51 na pohrebisku Zadowice. Tento hrot je datovaný do obdobia Przeworskej kultúry (Liana 1968, 382).

\section{Vertikálne v zásype a na dne hrobu}

Interpretačne pozoruhodnou kategóriou otáznych spôsobov ukladania kopijí/oštepov je skupina s exemplármi, ktorých hroty boli viac-menej vertikálne zapichnuté v zásypoch a dnách štyroch posudzovaných hrobov. Danú kategóriu viem sledovat len v období avarského kaganátu a v 10. 11. storočí. Vertikálne zapichnutý do dna hrobu bol konkrétne hrot z hrobu 10 na pohrebisku Cífer-Pác (Čilinská 1976, 83; Zábojník 1995, Tabelle III; hrob sa dá datovat do rokov 720 - 780) a hrot z hrobu A-405 z pohrebiska Kölked-Feketekapu A (Kiss 1996, 113, Abb. 20; hrobový celok sa podla hrobových príloh dá zaradit do rokov 568 - 650). V rámci prv uvedeného hrobu mohol byt hrot na základe informácií z nálezovej správy len zabodnutý vedla zomrelého (Čilinská 1976, 83), zatial' čo hrot $\mathrm{z}$ d’alšieho hrobu mohol spôsobit koňovi uloženému v hrobe aj smrt'. Ten bol totiž zabodnutý v 45 stupňovom uhle vedla pravej strany hrudného koša koňa. (Kiss 1996, 113, Abb. 20). Ďalšie dva skúmané objekty boli vertikálne zapichnuté do výplne hrobu. Bolo tomu tak v prípade hrobu z Tiszajenő-Kecskéspart (Kovács, L. 1978, 67, 72; hrob vieme zaradit do 10. storočia) a hrobu 1 z pohrebiska Bóly-Sziebert puszta A (tab. 2: 1; Papp 1963, 169, XXIX. tábla; hrob sa dá datovat' do rokov 720 - 750). Hrot žrd’ovo-bodnej zbrane z jazdeckého hrobu 1 z pohrebiska Bóly-Sziebert puszta A bol zapichnutý do výplne hrobovej jamy, konkrétne $77 \mathrm{~cm}$ nad jej dnom, v časti hrobu, kde sa nachádzal jazdec. Bližšie sa dá povedat, že zbraň pôvodne zapichli nad priestorom, ktorý na vertikálnej úrovni hraničil s pravým kolenom pochovaného jazdca, z jeho vonkajšej strany. Do kontextu štyroch vyššie spomenutých prípadov musím uviest', že zo sondy $\mathrm{P} / 22$ na pohrebisku Majs-Udvari rétek, ktoré je datované od konca 10. do konca 11. storočia (Kovács, L. 1978, 63, 67; Kiss 1983, 154), pochádza jeden hrot kopije/oštepu zabodnutý v híbke $50 \mathrm{~cm}$ medzi hrobmi pohrebiska, bez možnosti jeho priradenia k nejakému konkrétnemu hrobu.

Zo staršieho obdobia, presne v hroboch Przeworskej kultúry, boli hroty žrd’ovo-bodných zbraní tiež zapichávané vo výplni a do dna hrobov alebo urien, nachádzajúcich sa v nich (Liana 1968, 381-385; Czarnecka - Kontny 2009, 38-39). Rovnako aj v „nomádskom“ vrcholnostredovekom hrobe $\mathrm{z}$ Kriviny v dnešnom Bulharsku bol vertikálne zabodnutý hrot žrd’ovo-bodnej zbrane hned’ vedla panvy mŕtveho (Fiedler 2013, 264-265, Abb. 6: 4).

Niektoré stepné etniká, ako Kökturci (v 6. storočí), Mad’ari a Kazachovia, si preukázatelne udržiavali zvyk vztyčovania žrdovo-bodnej zbrane alebo len samotnej žrde/kolu na ich hroboch. Madari a Kazachovia si uvedený zvyk zachovali až do priebehu 19. a 20. storočia (Kovács, L. 1978, 71-72; Toleubayev 2013, 158-160). Vdaka žrdovo-bodnej zbrani ukončenej hrotom alebo hrubému kolu zabodnutého pri hlave zomrelého mohol byt tento „zásobovaný“ mäsom či iným jedlom počas výročných spomienkových slávností, o čom informoval P. Pallas (1778) a v prípade

19 Ide o vyššie spomínaný hrob 709 a 757 z pohrebiska Tiszafüred-Majoros. 
uzbeckého chána Abul-Khayra († 1468) L. A. Kastanie (1911; podla Toleubayev 2013, 158). Pohrebiská Kazachov boli v 18. - 19. storočí umiestňované na kopcoch a vyvýšených miestach a nachádzali sa na nich hroby označované žrdou/kolom alebo kopijou/oštepom, na ktorej viali stužky, remienky alebo konská hriva. Rovnako sa na hroby významných jazdcov ukladali sedlá s kopijami/oštepmi, lukmi i šípmi. (Toleubayev 2013, 158-159). Podobným zvykom u Kazachov a Kirgizov sa javí vztyčovanie kopije/oštepu v obydlí zomrelého, na ktorej bola smútočná vlajočka (Solov'ev 2003, 141, Рис./Fig. 32). ${ }^{20}$

\section{Zabitie (koňa)?}

Dva hroty žrdovo-bodných zbraní sa objavili v rámci hrobov na takých miestach, že zbrane, ku ktorým patrili, mohli spôsobit smrtelné zranenia koňom pochovaným $\mathrm{v}$ daných nálezových celkoch. Uvedenými nálezovými celkami sú hrob koňa z Aradac-Mečka (Nagy 1959, 63, Taf. XVI) a hrob 121 z pohrebiska Veszprém-Jutas-Seredomb I. (Rhé - Fettich 1931, 26, Taf. 11). Prvý hrobový celok môžeme datovat do včasného a stredného ${ }^{21}$ stupňa obdobia avarského kaganátu a druhý celok iba do včasného stupňa obdobia avarského kaganátu. Na základe informácií z nálezových správ a nálezových okolností oboch celkov vieme, že dané dva hroty žrdovo-bodných zbraní sa našli v oblasti krčných stavcov kostier príslušných koní. Môžeme sa domnievat, že tu šlo o prípady zabitia koní kvôli ich l’ahšiemu deponovaniu do hrobu alebo to boli následky nám neznámych rituálnych praktík(?).

Spolahlivo však môžem konštatovat', že určite usmrtené kone sa do hrobov dávali v neúplnej podobe (zastupujúcej symbolicky celého koňa) už i vyše jedno storočie pred príchodom Avarov do Karpatskej kotliny, ${ }^{22}$ potom počas avarského kaganátu, ${ }^{23}$ no aj v 10. a 11. storočíi ${ }^{24}$ Slovenský medievista Michal Slivka $(2013,163)^{25}$ v jednej zo svojich štúdií uviedol, že ešte v neskorostredovekom období sa kone zabíjali minimálne v rámci královských pohrebov a rovno v kostoloch. Bolo tomu tak aj v prípade uhorského krála Karola I. Róberta z Anjou (1308 - 1342) či českého krála a rímskeho cisára Karola IV. (1347 - 1378).

20 Dokonca existovala aj farebná symbolika uvedených vlajočiek odrážajúca vek zomrelého. Biela zastupovala staršieho človeka, červená mladého a čierna človeka stredného veku. Okrem vlajočky sa na kopiji/ oštepu mohol nachádzat i symbol, pod ktorým mŕtvy chodil zaživa. Napríklad to mohol byta aj chvost jaka alebo žriebäta (Solov'ev 2003, 215, poznámka 3; Toleubayev 2013, 164).

21 Približne medzi rokmi 650 až 700.

22 Na longobardských a gepidských pohrebiskách sa popri celých koňoch v hrobových jamách nachádzali od polovice 6. storočia i ich časti, ako lebka, alebo aj ich postroj v hrobe pochovaného (Kiss 2016, 165).

23 Ak odhliadneme od hrobov koní v samostatnej hrobovej jame alebo v spoločnej hrobovej jame s pochovaným, tak sa objavuje aj zvyk dávat do hrobu len čast spomenutého zvierata. Evidujem však i zvyk (predovšetkým rozšírený východne od rieky Tisy), pri ktorom boli do hrobu ukladané len koncové kosti štyroch končatín a lebka v konskej koži (Csiky 2016, 158).

24 I v priebehu usídlovania sa madarských kmeňov v Karpatskej kotline vieme dokumentovat deponovanie lebky a koncových kostí štyroch končatín koňa v hroboch i obetných jámách. Spomenuté časti koňa boli uložené v jeho koži, no ojedinele sa vyskytovali aj bez nej (Révész 2003, 338; Türk 2014, 145-148; Vörös 2014, 112).

25 V tejto štúdii je i dalšia literatúra $\mathrm{k}$ danej téme. 


\section{Deformovanie a lámanie hrotov}

Poslednou diskutabilnou kategóriou sú hrobové celky, ktoré obsahujú hroty kopijí/oštepov deformované ohnutím alebo aj zlomením. Nálezy ohnutých hrotov žrdovo-bodných zbraní pochádzajú $\mathrm{z}$ dvoch porušených hrobov, $\mathrm{v}$ ktorých bol pochovaný kôň a jazdec s koňom. Danými hrobovými celkami sú konkrétne včasnoavarský hrob 108/2 z pohrebiska Csákberény-Orondpuszta [tab. 2: 4; László et al. 2015, 58, 236, Taf. 9: 1 (108/2), 56: 1 (108/2); hrob vieme datovat’ do najvčasnejšej fázy daného pohrebiska, a v absolútnych číslach medzi rok 568 a prelomom 6. a 7. storočia] a neskoroavarský hrob X z pohrebiska Žitavská Tôň (tab. 2: 3; Budinský-Krička 1956, 18, tab. XIX.: 21, obr. 5; hrob sa dá zaradit do rokov 750 - 780). V neposlednom rade sa prekvapivo v neporušenom jazdeckom hrobe z lokality Stari Jankovci-Gatina objavil zlomený hrot kopije/oštepu (tab. 2: 2; Šmalcelj 1992, 48-49, obrázok na strane 48; Filipec 2015, Sl. 5; hrot vieme datovat do druhej polovice 7. storočia). Z hrotu bola konkrétne zlomená jeho tulajka. Podla nálezovej situácie musíme konštatovat fakt, že už takto poškodená zbraň bola do hrobu pravdepodobne uložená.

Môžeme vychádzat z predpokladu, že pertraktované ohnutie hrotov mohli iniciovat' bud' neznáme kultové alebo náboženské praktiky, alebo boli hroty poškodené počas boja. Ohnutím sa deformovali už špičky hrotov žrdovo-bodných zbraní ukladaných do hrobov Przeworskej kultúry (Czarnecka - Kontny 2009, 36-37). Navyše iné exempláre, ktoré mali ohnuté špičky alebo boli deformované odlišným spôsobom máme dokumentované v laténskych hroboch a hroboch doby rímskej z území susediacich (Czarnecka - Kontny 2009, 30, 36-37) i nesusediacich ${ }^{26}$ priamo s Przeworskou kultúrou. To, že už dva preberané hroty z Karpatskej kotliny nemuseli byt deformované len z rituálnych príčin, ale aj v dôsledku boja, dokazujú aj výsledky experimentálnej archeológie. Dá sa to demonštrovat aj experimentami, ktorými sa testovalo vrhanie a vrážanie replík žrd’ovo-bodných zbraní z okolia kultového domu v Uppåkra v súčasnom Švédsku ${ }^{27}$ na alebo do rozličných pevných cielov. Konkrétne šlo o asfalt, kameň, puklicu štítu a drevenú stenu (Andersson 2012, 80-88, Fig. 1-9). Aj na základe experimentov pod vedením Olleho Anderssona môžeme usudzovat, že deformované exempláre z Karpatskej kotliny ${ }^{28}$ nemuseli byt' iba rituálne ohýbané, no mohli byt i vrhané na prípadné drevo štítu alebo mohli byt' do neho vrážané (Andersson 2012, Fig 9a, 9b).

Obe možnosti boli svojím spôsobom písomnými prameňmi potvrdené. Konkrétne nám tieto obe hypotézy umožňujú akceptovat' minimálne dva písomné pramene z obdobia antiky. Paulus Orosius $(380 / 385$ - 420) z Galície nám zanechal zmienku o tom, ako bola rituálne ničená všetka získaná korist' Germánmi a Keltami na konci 2. storočia pred n. 1. (Pavli Orosii Historiarvm adversvm paganos V, 16; Orosius 1889, 164). ${ }^{29}$ Grék Arrianos $(95$ - 175) nám vo svojom po grécky

26 Pozri napríklad: Brunaux - Rapin 1988, 109 n.; Măndescu 2012, 345-347, 349-351.

27 Uvedené zbrane boli zaradené (Nilsson 2015, 81) do severskej rímskej doby železnej (cirka v rokoch 0 400) a doby vikingskej (cirka 9. storočie až rok 1066). Ohnuté alebo iným spôsobom deformované hroty kopijí/oštepov nájdeme v nálezových celkov spojených s vodnými plochami, močiarmi alebo mokrinami na švédskom ostrove Gotland (Müller-Wille 1999, 77). Vo všeobecnosti sa dá povedat', že vo včasnom stredoveku boli artefakty pred ich deponovaním úmyselne ničené najmä a práve v Škandinávii (Härke 2014, 43).

28 Podla štýlu ohnutia.

29 „LXXX milia Romanorum sociorumque ea tempestate trucidata, XL milia calonum atque lixarum interfecta Antias scribit. ita ex omni penitus exercitus decem tantummodo homines, qui miserum nuntium ad augendas meserias reportarent, superfuisse referuntur. hostes binis castris atque ingenti praeda potiti noua quadam atque insolita exsecratione cuncta quae ceperant pessum dederunt; uestis discissa et proiecta est, aurum argentumque in flumen abiectum, loricae uirorum concisae, phalerae equorum disperditae, equi ipsi gurgitibus inmersi, homines laqueis collo inditis ex arboribus suspensi sunt, ita ut nihil praedae uictor, nihil misericordiae uictus adgnosceret." 
písanom diele z roku 135 n. l., známom skôr pod latinským označením „Acies contra Alanos“, zanechal zmienku o tom, že pilá ${ }^{30}$ legionárov 12. légie sa zvykli ohýbat po tom, čo prenikali tažkým brnením tiel alanských nepriatelov (Acies contra Alanos; Arrianos 1968, 181-182; 2002; Andersson 2012, 82). ${ }^{31}$

\section{Diskusia}

V predchádzajúcich riadkoch som ponúkol svoje pohlady na (podla mňa) osem diskutabilných skupín deponovania kopijí alebo oštepov v priestore Karpatskej kotliny vo včasnom stredoveku.

V písomných alebo etnografických prameňoch nie je na základe mne dostupných informácií opora pre fenomén zabodávania kopijí/oštepov do stien hrobových komôr, pre kladenie daných zbraní šikmo nad a pod zomrelým alebo koňom, deponovanie na a pod drevenou hrobovou konštrukciou alebo pre horizontálne ukladanie v zásype hrobovej jamy. Skracovanie žrdí žrdovo-bodných zbraní pre ich možné lepšie uloženie v rámci drevenej konštrukcie a mimo nej v hrobovej jame sa taktiež nedá dostatočne vysvetlit vd’aka nearcheologickým prameňom. Uspokojivé vysvetlenie nepodáva ani dávny zvyk Kazachov lámat’ kopiju/oštep mŕtveho rok od jeho smrti v mieste jej žrde.

Naopak, určitú oporu v prameňoch nájdeme pre vertikálne zabodávanie žrd’ovo-bodnej zbrane v zásype a na dne hrobu (v historických i etnografických prameňoch), zabíjanie koní zbraňami (v historických prameňoch neskorého stredoveku) a tiež pre deformovanie alebo lámanie hrotov žrd’ovo-bodných zbraní (v antických a včasnostredovekých historických prameňoch, ako aj $\mathrm{v}$ experimentálnej archeológii). V rámci týchto troch otáznych spôsobov deponovania vystupuje do popredia vertikálne zabodávanie, spojené jasne s konkrétnymi funerálnymi praktikami európskych a ázijských stepných etník. V sledovanom časovom horizonte sa daný jav v rámci Karpatskej kotliny vyskytoval práve v období avarského kaganátu a 10. až 11. storočia.

V neposlednom rade môžeme konštatovat, že všetkých osem otáznych spôsobov deponovania kopijí/oštepov bolo vykonávaných v období avarského kaganátu. Pritom len v troch prípadoch - v prípade uloženia kopijí/oštepov šikmo nad zomrelým alebo koňom, mimo alebo $\mathrm{v}$ rámci drevenej konštrukcie, či na nej alebo pod ňou - sa pertraktovaný jav objavil aj v 9. storočí alebo $\mathrm{v}$ prvej polovici 10. storočia $\mathrm{v}$ prípade nemad’arských hrobových celkov v naddunajskom priestore Karpatskej kotliny. Tiež vieme povedat, že väčšina hrotov kopijí/oštepov, ktorá sa našla v rámci drevených konštrukcií, je datovaná do 9. storočia až prvej polovice 10. storočia. Menej hrotov $\mathrm{v}$ tejto kategórii patrí do obdobia avarského kaganátu. Pri hrotoch nájdených mimo drevenej konštrukcie dominujú však už exempláre z obdobia avarského kaganátu a hroty z obdobia 9. storočia a prvej polovice 10. storočia sú $\mathrm{v}$ menšine. Nakoniec už spomínané vertikálne zabodávanie

30 Z kontextu predchádzajúceho textu vyznieva, že muselo íst’ o pilum, aj ked' autor spomína na danom mieste ohýbanie kontu (kontos) legionárov.

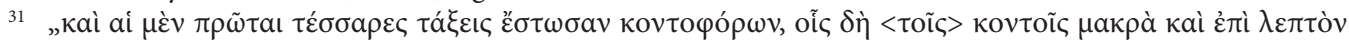

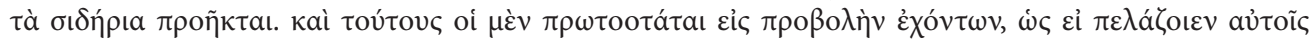

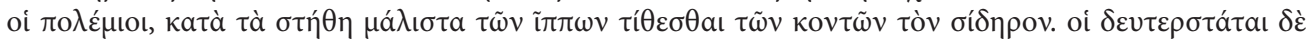

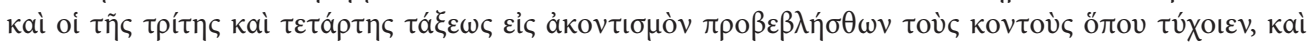

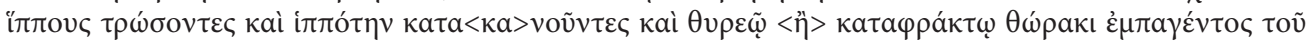

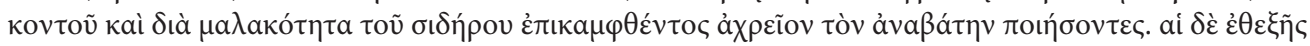

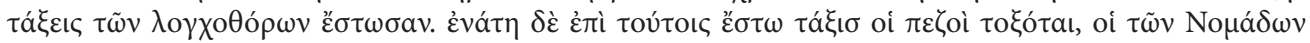

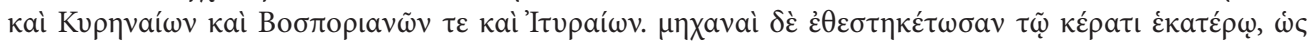

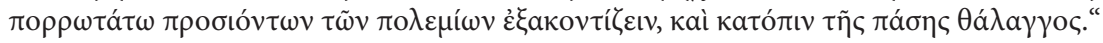


hrotov do zásypu alebo dna hrobu sa viaže na obdobie hegemónie Avarov a Madarov na území Karpatskej kotliny.

\section{REFERENCES}

\section{Primary sources}

Arrianos. 1968. Acies contra Alanos. In Roos, A. G. (ed.). Flavivs Arrianvs II. Scripta minora et fragmenta. Lipsia.

Arrianos. 2002. Acies contra Alanos. van Dorst, Sander (ed.). Arrian's Array against the Alans. http://members.tripod.com/ S_van_Dorst/Ancient_Warfare/Rome/Sources/ektaxis. html\#T7 .

Orosius. 1889. Pavli Orosii Historiarvm adversvm paganos. In Zangemeister, Karl Friedrich Wilhelm (ed.). Pavli Orosii Historiarvm adversvm paganos libri VII. Accedit eivsdem Liber apologeticvs. Recensvit et commentario critico instrvxit Carolvs Zangemeister. Vindobona.

\section{Secondary sources}

Andersson, Olle. 2012. Spjuten från Uppåkra - ritualförstörda eller förbrukade? In Fornvännen 107, 80-88.

Bárdos, Edith - Garam, Éva. 2009. Das awarenzeitliche Gräberfeld in Zamárdi-Rétiföldek. Teil I. Budapest.

Bárdos, Edith - Garam, Éva. 2014. Das awarenzeitliche Gräberfeld in Zamárdi-Rétiföldek. Teil II. Budapest.

Brunaux, Jean-Louis - Rapin, André. 1988. Gournay II. Boucliers et lances, dépôts et trophées. Paris - Amiens.

Budinský-Krička, Vojtech. 1956. Pohrebisko z neskorej doby avarskej v Žitavskej Tôni na Slovensku. In Slovenská archeológia IV/1, 5-131.

Csiky, Gergely. 2015. Avar-Age Polearms and Edged Weapons. Classification, Typology, Chronology and Technology. Leiden - Boston.

Csiky, Gergely. 2016. The Religion of Steppe Nomads. In Tóth, Endre - Vida, Tivadar - Takács, Imre (eds.). Saint Martin and Pannonia. Christianity on the Frontiers of the Roman World. Exhibition Catalogue. Györ, 152-160.

Czarnecka, Katarzyna - Kontny, Bartosz. 2009. Traces of combat or traces of ritual destruction? Damage to weapons in the Przeworsk culture. In Hans-Joachim Schalles - Alexandra W. Busch (eds.). Waffen in Aktion. Akten des 16. ROMEC, Xanten, 13.-16. Juni 2007, "Xantener Berichte" XVI. Mainz am Rhein, 29-40.

Čilinská, Zlata. 1976. Pohrebisko z 8. storočia v Cíferi-Páci. In Archeologické výskumy a nálezy na Slovensku 1975, 82-85.

Eisner, Jan. 1952. Devínska Nová Ves. Slovanské pohřebiště. Bratislava.

Fiedler, Uwe. 2013. Zur Suche nach dem archäologischen Niederschlag von Petschenegen, Uzen und Kumanen in den Gebieten südlich der unteren Donau. In Curta, Florin - Maleon, Bogdan-Petru (eds.). The Steppe Lands and the World Beyond Them. Studiem in honor of Victor Spinei on his 70th Birthday. Iaşi, 249-286.

Filipec, Krešimir. 2015. Donja Panonija od 9. do 11. stoljeća. Sarajevo. 
Fusek, Gabriel. 2006. Výklenkové hroby na včasnostredovekom pohrebisku v Cíferi, v časti Pác. In Študijné zvesti Archeologického ústavu Slovenskej akadémie vied 39, 27-54.

Garam, Éva. 1995. Das awarenzeitliche Gräberfeld von Tiszafüred. Cemeteries of the Avar Period (567-829) in Hungary 3. Budapest.

Gardeła, Leszek. 2014. Viking Death Rituals on the Isle of Man. In Gardeła, Leszek - Larrington, Carolyne (eds.). Viking Myths and Rituals on the Isle of Man. Nottingham, 30-38.

Hanuliak, Milan. 1990. Aussagefähigkeiten archäologischer Quellen aus Flachgräberfeldern des 9.-12. Jahrhunderts. In Slovenská archeológia XXXVIII/1, 147-192.

Hanuliak, Milan. 2004. Velkomoravské pohrebiská. Pochovávanie v 9.-10. storočí na území Slovenska. Nitra.

Hanuliak, Milan - Rejholcová, Mária. 1999. Pohrebisko v Čakajovciach (9.-12. storočie). Vyhodnotenie. Bratislava.

Härke, Heinrich. 2014. Grave goods in early medieval burials: messages and meanings. In Mortality 19/1, 41-60.

Holman, Katherine. 2012. The Northern Conquest. Vikings in Britain and Ireland. Digital edition. Oxford.

Husár, Martin. 2015. Thrusting pole arms in the early medieval graves from the Carpathian Basin. In Pinter, Zeno Karl - Niţoi, Anca. (eds.). Interethnic Relations in Transylvania. Militaria Mediaevalia in Central and South Eastern Europe. Proceedings of the 2014 conference. Sibiu, 7-26.

Chropovský, Bohuslav. 1957. Slovanské pohrebisko z 9. st. vo Velkom Grobe. In Slovenská archeológia $\mathrm{V} / 1,174-239$.

Chropovský, Bohuslav. 1986. Nálezová správa Archeologického ústavu Slovenskej akadémie vied č. 11705/86. Nitra.

Müller-Wille, Michael. 1999. Opferkulte der Germanen und Slawen. Archäologie in Deutschland. Sonderheft 1999. Stuttgart.

Kiss, Attila. 1983. Baranya megye X-XI. századi sírleletei. Magyarország honfoglalás és kora Árpád-kori temetőinek leletanyaga 1. Budapest.

Kiss, Attila. 1996. Das awarenzeitlich gepidische Gräberfeld von Kölked-Feketekapu A. Mit Beiträgen von Max Martin, Peter Stadler und István Takács. Monographien zur Frühgeschichte und Mittelalterarchäologie 2. Innsbruck.

Kiss, Attila. 2001a. Das awarenzeitliche Gräberfeld in Kölked-Feketekapu B. Teil I. Budapest. Kiss, Attila. 2001b. Das awarenzeitliche Gräberfeld in Kölked-Feketekapu B. Teil II. Budapest.

Kiss, Attila P. 2016. Traces of the Germanic Belief System in the Carpathian Basin. In Tóth, Endre Vida, Tivadar - Takács, Imre (eds.). Saint Martin and Pannonia. Christianity on the Frontiers of the Roman World. Exhibition Catalogue. Györ, 161-170.

Kovács, István. 1913. A mezőbándi ásatások. Les fouilles de Mezőbánd. In Dolgozatok az Erdélyi Nemzeti Múzeum Érem- és Régiségtárából 4, 279-389.

Kovács, László. 1978. Über die ungarischen Lanzen aus dem 10.-11. Jahrhundert. In Mitteilungen des Archäologischen Instituts der Ungarischen Akademie der Wissenschaften 7/1977, 61-73.

Kovács, László. 1982. Die Waffen der landnehmenden Ungarn: Säbel, Kampfäxte, Lanzen (Diss. Thesen). In Mitteilungen des Archäologischen Instituts der Ungarischen Akademie der Wissenschaften 10-11, 243-255, 433-438.

Kurasiński, Tomasz. 2014. Grotem w dól, grotem w górę. Deponowanie włóczni w grobach wczesnośredniowiecznych na ziemiach Polskich. In Kurasiński, Tomasz - Skóra, Kalina (eds.). Grób w przestrzeni, przestrzeń w grobie. Przestrzenne uwarunkowania w dawnej obrzędowości pogrzebowej (Acta Archaelogica Lodziensia 60). Łódź, 159-190. 
László, Gyula et al. 2015. Das awarenzeitliche Gräberfeld in Csákberény-Orondpuszta. Monumenta Avarorum Archaeologica. Vol. 11. Budapest.

Liana, Teresa. 1968. Niektóre zwyczaje pogrzebowe ludności kultury przeworskiej. In Wiadomości Archeologiczne XXXIII/3-4, 381-385.

Măndescu, Dragoș, 2012. Killing the Weapons. An Insight on Graves with Destroyed Weapons in Late Iron Age Transylvania. In Berecki, Sándor (ed.). Iron Age Rites and Rituals in the Carpathian Basin. Proceedings of the International Colloquium from Târgu Mureș, 7-9 October 2011. Târgu Mureș, 343-356.

Mesterházy, Károly. 1987. Korai avar részleges lovastemetkezések Ártándról és Biharkeresztesről. In Folia Archaeologica. Annales Musei Nationalis Hungarici XXXVIII, 219-246.

Nagy. Sándor. 1959. Die Nekropole bei Aradac aus dem frühen Mittelalter. In Rad Vojvođanskih Muzeja 8, 45-102.

Papp, László. 1963. A bolyi avarkori temető I. In Janus Pannonius Múzeum Évkönyve 1962, 163-189.

Pedersen, Anne. 2014a. Dead Warriors in Living Memory. A Study of Weapon end Equestrian Burials in Viking-Age Denmark, AD 800-1000. Publications from the National Museum, Studies in Archaeology \& History Vol. 20:1 1. Text. Jelling Series. Copenhagen.

Pedersen, Anne. 2014b. Dead Warriors in Living Memory. A Study of Weapon end Equestrian Burials in Viking-Age Denmark, AD 800-1000. Publications from the National Museum, Studies in Archaeology \& History Vol. 20:1 2. Catalogue. Jelling Series. Copenhagen.

Pohl, Walter. 1988. Die Awaren. Ein Steppenvolk in Mitteleuropa, 567-822 n. Chr. München.

Price, Neil. 2004. The Archaeology of Seiðr: Circumpolar Traditions in Viking Pre-Christian Religion. In Brathair 4/2, 109-126.

Price, Neil. 2008. Dying and the dead: Viking Age mortuary behaviour. In Brink, Stefan - Price, Neil (eds.). The Viking World. Abington - New York, 257-273.

Révész, László. 2003. The Cemeteries of the Conquest Period. In Visy, Zsolt (ed.). Hungarian Archaeology at the Turn of the Millennium. Budapest, 338-343.

Rhé, Gyula-Fettich, Nándor. 1931. Jutas und Öskü. ZweiGräberfelder aus der Völkerwanderungszeit in Ungarn. Skythika IV. Prag.

Salamon Ágnes - Erdélyi István. 1971. Das völkerwanderungszeitliche Gräberfeld von Környe. Studia Archaeologica 5. Budapest.

Slivka, Michal. 2013. Symbolika výzbroje a výstroja. Militia est vita hominis super terram (Jób 7, 1). In Slivka, Michal (ed.). Pohlady do stredovekých dejín Slovenska (Res intrinsecus lectae). Martin, 154-165.

Šmalcelj, Marija. 1992. Stari Jankovci - Gatina. In Jurkić-Girardi, Vesna (ed.). Arheologija i rat: djelatnost Arheološkog zavoda Filozofskog fakulteta Sveučilišta u Zagrebu. Archeology and War: Research Undertaken by the Department of Archeology at the Faculty of Philosophy, University of Zagreb. Zagreb, 48-49.

Solov'ev, Aleksandr I. 2003. Оружие и Доспехи. Сибирское вооружение: от каменного века до средневековья. [Arms and Armour. Siberian Weaponry: from the Stone Age to the Middle Ages]. Novosibirsk.

Sós, Ágnes Cs. - Salamon, Ágnes. 1995. Cemeteries of the Early Middle Ages (6th-9th Centuries AD) at Pókaszepetk. Budapest.

Szentpéteri, József. 2002. Archäologische Denkmäler der Awarenzeit in Mitteleuropa. Budapest.

Štefanovičová, Tatiana. 1996. Probleme der Entwicklung der Slowakei im 9. Jh. In Bialeková, Darina - Zábojník, Jozef (eds.). Ethnische und kulturelle Verhältnisse an der mittleren Donau vom 6. bis zum 11. Jahrhundert. Symposium, Nitra, 6. bis 10. November 1994. Bratislava, 257-265. 
Točík, Anton. 1968a. Slawisch-awarisches Gräberfeld in Štúrovo. Bratislava.

Točík, Anton. 1968b. Slawisch-awarisches Gräberfeld in Holiare. Bratislava.

Točík, Anton. 1971. Flachgräberfelder aus dem IX. und X. Jahrhundert in der Südwestslowakei. In Slovenská archeológia XIX/1, 135-276.

Toleubayev, Abdesh Tashkenovich. 2013. Traditional Beliefs and Superstitious Rites of the Kazakhs. Almaty.

Tomka, Péter. 2000. Gräberfeld aus dem 9. Jh. in Páli-Dombok (Kom. Győr-Sopron-Moson). In Communicationes archaeologicae Hungariae 2000, 177-210.

Török, Gyula. 1973. Sopronkőhida IX. századi temetője. Budapest.

Türk, Attila. 2014. Towards a Classification of Grave Types and Burial Rites in the 10th-11th Century Carpathian Basin - Some Remarks and Observations. In Doncheva-Petkova, Lyudmila - Balogh, Csilla - Türk, Attila (eds.). Avars, Bulgars and Magyars on the Middle and Lower Danube. Proceedings of the Bulgarian-Hungarian Meeting, Sofia, May 27-28, 2009. Sofia - Piliscsaba, 137-156.

Vörös, István. 2014. Animal Husbandry and Land Cultivation in the Conquest Period and the Early Arpadian Age. In Révész, László (ed.). The Era of the Hungarian Conquest. Permanent Exhibition of the Hungarian National Museum. Budapest, 111-121.

Zábojník, Jozef. 1995. Soziale Problematik der Gräberfelder des nördlichen und nordwestlichen Randgebietes des awarischen Kaganats. In Slovenská archeológia XLIII/2, 205-344.

Zábojnik, Jozef. 2009. Slovensko a avarský kaganát. Druhé prepracované a doplnené vydanie. Bratislava.

SUMMARY: AN ATTEMPT TO EXPLAIN SOME DEBATABLE WAYS OF DEPOSITIONS OF SPEARS, LANCES, OR JAVELINS IN GRAVES OF THE EARLY MEDIEVAL CARPATHIAN BASIN. The referred article focuses on debatable depositions of thrusting pole arms in early medieval graves of the Carpathian Basin. The author of the article dealt with the era of the Avar Khaganate, the 9th century and the era of the 10th - 11th centuries. According to the available data in primary literary and ethnographic sources, there is no proof of the phenomenon of the sticking of thrusting pole arms into the walls of a grave pit (Pl. 1: 1-2), oblique deposition of the given weapons over and under the deceased or a dead horse (Pl. 1: 3), their depositions on or under a wooden construction, or their horizontal depositions in the filling of the grave. The shortening of poles of spears, lances, or javelins to fit them into grave pits, namely within the frame of the wooden construction (Pl. 1:4) or outside of it (Pl. 1:5), also cannot be sufficiently explained by the help of the archaeological sources. Not even the ancient habit of the Kazakhs provides a satisfactory explanation. It concerned the breaking of the spear (in the part of the pole), which belonged to the deceased. This event took place one year after the death of the deceased. On the contrary, the author saw a certain support for the vertical sticking into the filling and the bottom of a grave (Pl. 2: 1; in historic and ethnographic sources), killing of a horse by a weapon (in historic sources of the Late Middle Ages), and the deforming (Pl. 2: 3-4) or breaking (Pl. 2: 2) of the head of a trusting pole weapon (in antique and early medieval historic sources as well as in experimental archaeology) in non-archaeological sources. Within the framework of the debatable ways of the aforementioned depositions, it should be noticed that vertical sticking is clearly connected with particular funerary practices of European and Asian steppe ethnic groups. In the examined time horizon, the stated phenomenon appeared in the Carpathian Basin right in the period of Avar Khaganate and then in the 10th - 11th centuries. Last but not least, the author of the article claimed that all eight abovementioned ways of depositions were performed in the time of the Avar Khaganate. In the 9th century and the first half of the 10th century (regarding the non-Hungarian graves in the territory over the Danube River), the discussed phenomenon also emerged in three cases of thrusting pole arms' depositions, 
namely in the case of oblique deposition over the deceased or a dead horse, deposition within a wooden construction or outside of it, and finally the deposition on or under a wooden construction. Most thrusting pole arms, which were buried within wooden constructions, are dated to the 9th century - the first half of the 10th century. But the majority of specimen, which were placed outside the wooden constructions, belonged to the time of the Avar Khaganate. In the end the above mentioned vertical sticking of a thrusting pole weapon into the filling and the bottom of a grave is related to the time of the hegemony of the Avars and the Hungarians in the Carpathian Basin.

\author{
Mgr. Martin Husár, PhD. \\ Constantine the Philosopher University in Nitra \\ Faculty of Arts \\ Institute for Research of Constantine and Methodius' Cultural Heritage \\ Trieda A. Hlinku 1 \\ 94974 Nitra \\ Slovakia \\ mhusar@ukf.sk
}




\section{Prílohy / Appendix:}

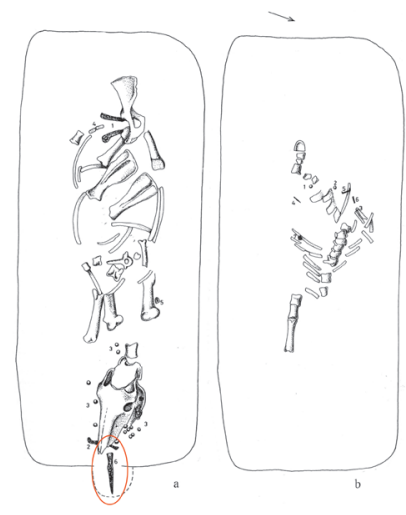

1

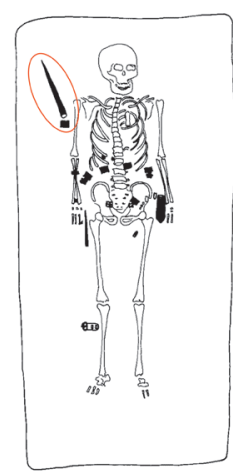

3

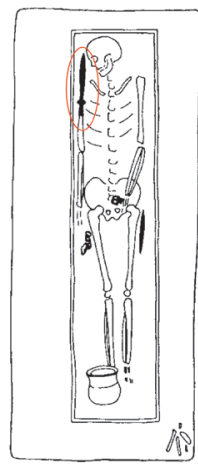

$\stackrel{10 \mathrm{~cm}}{\complement n}$

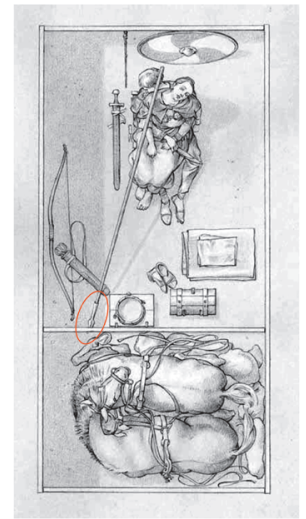

2

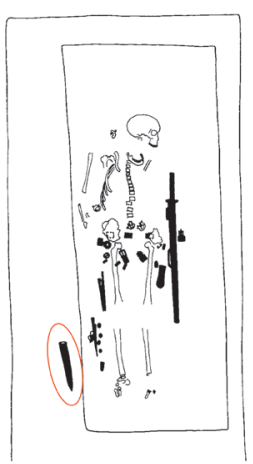

5

Tabulka 1. Vybrané včasnostredoveké hroby z Karpatskej kotliny a súčasného Švédska týkajúce sa otáznych spôsobov deponovania kopijí a oštepov.

Zabodávanie žrd’ovo-bodných zbraní do stien hrobovej jamy (1-2); ich šikmé ukladanie nad (3) a pod zomrelým alebo mŕtvym koňom; skracovanie žrdí kopijí a oštepov, aby sa vošli do hrobových jám, konkrétne v rámci drevených konštrukcií (4) alebo mimo nich (5).

1. Hrob 1634, Zamárdi-Réti földek dűlő, Madarsko (Bárdos - Garam 2009, 30, 32, Abb. 14); 2. Hrob Bj.834, Birka, Švédsko (Price 2008, 268, Fig. 19.4); 3. Hrob 199, Tiszafüred-Majoros, Madarsko (Garam 1995, 32, Abb. 12); 4. Hrob 60, Sopron-Sopronkőhida, Mad’arsko (Török 1973, 18; 9. ábra); 5. Hrob 496, Tiszafüred-Majoros, Madarsko (Garam 1995, 65, Abb. 27).

Plate 1. Selected early medieval graves from the Carpathian Basin and present-day Sweden regarding the debatable ways of depositions of thrusting pole arms.

The sticking of thrusting pole arms into the walls of a grave pit (1-2); oblique deposition of them over (3) and under the deceased or a dead horse; shortening of poles of spears, lances, or javelins to fit them into grave pits, namely within the frame of the wooden construction (4) or outside of it (5).

1. Grave 1634, Zamárdi-Réti földek dülő, Hungary (Bárdos - Garam 2009, 30, 32, Abb. 14); 2. Grave Bj.834, Birka, Sweden (Price 2008, 268, Fig. 19.4); 3. Grave 199, Tiszafüred-Majoros, Hungary (Garam 1995, 32, Abb. 12); 4. Grave 60, Sopron-Sopronkőhida, Hungary (Török 1973, 18; 9. ábra); 5. Grave 496, Tiszafüred-Majoros, Hungary (Garam 1995, 65, Abb. 27). 

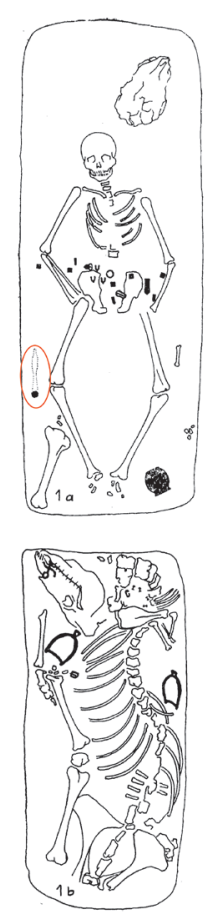

1

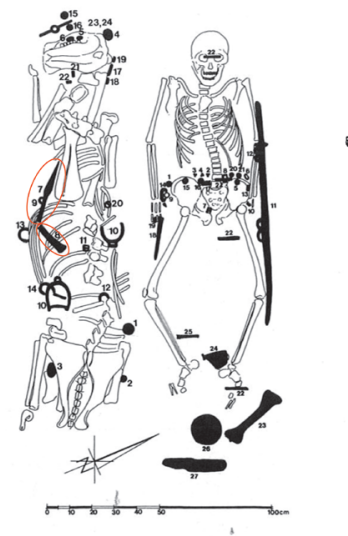

2

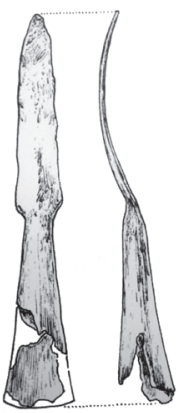

3

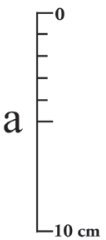

4

Tabulka 2. Vybrané včasnostredoveké hroby a hroty z Karpatskej kotliny týkajúce sa otáznych spôsobov deponovania kopijí a oštepov.

Vertikálne zabodávanie žrdovo-bodných zbraní v zásype a na dne hrobu (1); lámanie (2) a deformovanie (3-4) hrotov žrdovo-bodných zbraní.

1. Hrob 1, Bóly-Sziebert puszta A, Madarsko (Papp 1963, 169, XXIX. tábla); 2. Hrob, Stari Jankovci-Gatina, Chorvátsko (Šmalcelj 1992, 48-49, obrázok na strane 48; Filipec 2015, Sl. 5); 3. Hrot kopije/oštepu, hrob X, Žitavská Tôň, Slovensko (Budinský-Krička 1956, 18, tab. XIX.: 21); 4. Hrot kopije/oštepu, hrob 108/2, Csákberény-Orondpuszta, Madarsko [László et al. 2015, 58, Taf. 9: 1 (108/2)]. Čísla 3-4 sú v mierke označenej písmenom „““.

Plate 2. Selected early medieval graves and heads from the Carpathian Basin regarding the debatable ways of depositions of thrusting pole arms.

The vertical sticking of thrusting pole arms into the filling and the bottom of a grave (1); breaking (2) and deforming (3-4) of heads of trusting pole arms.

1. Grave 1, Bóly-Sziebert puszta A, Hungary (Papp 1963, 169, XXIX. tábla); 2. Grave, Stari Jankovci-Gatina, Croatia (Šmalcelj 1992, 48-49, figure on page 48; Filipec 2015, Sl. 5); 3. Head of a thrusting pole weapon, grave X, Žitavská Tôň, Slovakia (Budinský-Krička 1956, 18, tab. XIX.: 21); 4. Head of a thrusting pole weapon, grave 108/2, Csákberény-Orondpuszta, Hungary [László et al. 2015, 58, Taf. 9: 1 (108/2)]. Numbers 3-4 are according to the scale marked with the letter "a". 